\title{
Relationships between NW flow snowfall and topography in the Southern Appalachians, USA
}

\author{
L. Baker Perry ${ }^{1,2, *}$, Charles E. Konrad ${ }^{2}$ \\ ${ }^{1}$ Department of Geography and Planning, Box 32066, Appalachian State University, Boone, North Carolina 28608, USA \\ ${ }^{2}$ Department of Geography, CB\# 3220, University of North Carolina at Chapel Hill, Chapel Hill, North Carolina 27599, USA
}

\begin{abstract}
NW flow snowfall (NWFS) events are common occurrences at higher elevations (1500 to $>2000 \mathrm{~m}$ a.s.l.) and on windward slopes in the Southern Appalachian Mountain region of the southeastern USA. The spatial patterns of NWFS are strongly controlled by topography, resulting in pronounced spatial variability. The strong topographic and low-level convective forcing, coupled with low temperatures and strong winds, increases societal impacts. This paper analyzes the relationships between NWFS and various topographic and geographic (TOPO/GEOG) variables in the Southern Appalachians. We identified NWFS events on the basis of low-level wind direction, extracted values for the TOPO/GEOG variables from Digital Elevation Models (DEMs), and developed statistical relationships between NWFS and the TOPO/GEOG variables. Using a multivariate regression model and GIS techniques, we also mapped mean annual NWFS across the region. Results indicate that elevation and NW exposure are most strongly correlated with NWFS; however, the strength of these relationships is mediated by temperature. In the colder NWFS events, the relative importance of elevation is diminished, while NW exposure and distance to a NW slope are relatively more important. Additionally, we demonstrate that multivariate regression modeling in conjunction with GIS techniques can be an effective way to map snowfall patterns associated with specific wind directions, particularly when a strong topographic control is evident.
\end{abstract}

KEY WORDS: Topographic influences · NW flow snowfall · Southern Appalachian Mountains

\section{INTRODUCTION}

Precipitation patterns in mountainous regions are highly complex and strongly influenced by the interaction of the topography and atmospheric circulation through orographic lifting and rainshadow effects. This is particularly the case with snowfall, where the importance of temperature on snow accumulation further magnifies the influence of elevation. The complexity of these spatial patterns of snowfall is not always evident, due to the sparse network of precipitation stations in many mountainous regions and their bias towards lowelevation sites. Previous attempts to better understand the relationships between precipitation and topography have used a variety of approaches, from simple linear regression models to physical-dynamical mathematical models of the atmosphere. The need is increasing for more accurate, spatially continuous estimates of snowfall to allow for effective hydrological modeling in regions where snowmelt is of hydrological and societal importance. Most estimates of snowfall and snowmelt have been calculated from average annual or monthly precipitation data, which represents the combined effects of many different synoptic patterns of atmospheric circulation. Further study is required of the relationships between snowfall patterns and topographic characteristics for low-level wind directions associated with different synoptic patterns in mountainous regions.

This is especially the case in the Southern Appalachian Mountain region of the southeastern USA, where accumulating snowfall can occur in association with a variety of synoptic patterns and low-level wind directions to yield mean annual snowfall totals of up to $250 \mathrm{~cm}$ at the highest elevations. NW flow snowfall (NWFS) is the most frequently occurring type of snowfall affecting the region and is responsible for as much 
as $50 \%$ of mean annual snowfall at higher elevations and along windward slopes (Perry 2006). In some cases, air trajectories extend downwind from the Great Lakes and may act to enhance snowfall (Perry et al. in press). Schmidlin (1992) also found that the NWFS with a Great Lakes connection accounts for nearly $30 \%$ of mean annual snowfall totals in the northern mountains of West Virginia.

In this study, we developed statistical relationships between NWFS and 17 different topographic and geographic (TOPO/GEOG) variables in the Southern Appalachian Mountain region of the southeastern USA. In particular, 3 research questions serve to guide the study: (1) What are the statistical relationships between NWFS and TOPO/GEOG variables? (2) How do these relationships vary between different types of NWFS events? and (3) Which TOPO/GEOG variables together account for the greatest variance in snowfall totals? The study also uses GIS techniques to illustrate the spatial patterns of NWFS. This methodology helps illuminate relationships between a particular type of snowfall event and topography in the Southern Appalachians.

\section{BACKGROUND}

Precipitation amounts generally increase with elevation in the middle latitudes due, to orographic effects as air is forced to rise up a mountain barrier (Barry 1992, Basist et al. 1994). Most of this enhancement occurs via the 'seeder-feeder' effect, whereby synoptic-scale precipitation falling from middle and high-level seeder clouds grows in size through scavenging of cloud droplets from the low-level feeder clouds produced by upslope orographic flow. In a warm atmosphere with low-level cloud temperatures above $0^{\circ} \mathrm{C}$, falling raindrops grow via enhanced collision-coalescence processes in the feeder cloud, whereas at temperatures below $0^{\circ} \mathrm{C}$, falling snow crystals grow via riming, or the freezing of supercooled water droplets (Pruppacher \& Klett 1997). Snow crystals, due to their lower fall speeds and larger surface area, are much more effective scavengers of low-level moisture from the feeder clouds than raindrops (Choularton \& Perry 1986). For this reason, Choularton \& Perry (1986) and Dore et al. (1992) have suggested that orographic effects on windward slopes and at higher elevations are even more pronounced for snow than for rain. Since the low-level feeder cloud is more effectively scavenged by falling snow crystals, significantly less low-level moisture is available on leeward slopes and at lower elevations, resulting in more pronounced shadowing effects as well (Choularton \& Perry 1986, Dore et al. 1992). Due to the effects of such shadowing, the relationship between precipitation and elevation is not straightforward, since exposure to moist low-level winds and the locations of upwind blocking barriers are important influences that in many cases weaken this relationship. Consequently, most studies investigating precipitation relationships in mountains have included elevation plus additional topographic variables such as exposure, slope, and distance to windward slope.

One approach for understanding precipitationtopography relationships has been the development of high resolution physical-dynamical mathematical models of precipitation processes for particular mountain areas (Abbs \& Pielke 1987, Oki et al. 1991, Katzfey 1995, Farley et al. 2000, Poulos et al. 2002). In these numerical models, the topographic variables of elevation and exposure have a strong influence on the modeled spatial patterns of precipitation. The physical interactions among atmospheric circulation, moisture, and topography are not well understood, however, limiting the utility of these numerical models. The results of numerical modeling are very sensitive to initial conditions, which are challenging to measure in mountainous regions, where the station network is often sparse. Furthermore, significant computing resources are needed to run the models together with a digital elevation model (DEM) of sufficient spatial resolution to adequately capture the meso- and microscale nature of the orographic processes.

An alternative approach is to establish statistical relationships between precipitation and topographic characteristics using climatological precipitation data from a sample of stations representing a variety of topographic characteristics. This approach relies on a regression model with topographic variables (i.e. elevation, exposure, slope) as the independent variables and precipitation as the dependent variable. The multivariate regression model then allows precipitation values to be estimated using known values of the topographic variables for other locations. Donley \& Mitchell (1939), for example, found a positive linear relationship between elevation and precipitation in the Southern Appalachians, although the slopes of the above varied considerably with the region. Also in the Southern Appalachians, Smallshaw (1953) reported a linear relationship between precipitation and elevation, but found that precipitation totals actually decreased at the top of some steep narrow ridges due to wind effects.

In the Cascades of western Washington and Oregon, Schermerhorn (1967) showed a non-linear relationship between precipitation and elevation, but also stressed the importance of upwind blocking barriers and the large-scale topography in controlling precipitation patterns. For example, in the prevailing westerly flow across the Pacific Northwest, the Olympic Mountains serve as an important upwind blocking barrier for 
areas to the east, such as Puget Sound and Seattle, by reducing the precipitable moisture. Precipitation amounts can also be considerably enhanced at low elevation stations in close proximity to high elevation peaks due to the enhanced orographic effect. In a watershed in Nevada, Hevesi et al. (1992) used elevation as the sole independent variable to estimate average annual precipitation using multivariate geostatistics and found cokriging, a method in which kriging is associated with elevation, to provide the best results. Basist et al. (1994) developed statistical relationships between precipitation and topographic characteristics in 10 different mountainous regions ranging from equatorial to marine west coast regions and found that the combined effects of elevation and exposure to the prevailing wind are the most important factors influencing precipitation. In addition, they found that topographic influences explained a greater proportion of the variability of average annual precipitation in the middle-latitude mountainous regions in comparison to the equatorial regions. However, we are familiar with no previous study using these approaches that took snowfall as the dependent variable.

Recent studies have coupled the statistical approach described above with the spatial analytical capabilities of GIS to assess the relationships between precipitation and topography (Daly et al. 1994, Martínez-Cob 1996, Goovaerts 2000, Ninyerola et al. 2000, Weisse \& Bois 2001, Daly et al. 2002, Marquínez et al. 2003). The PRISM (Parameter-elevation Regressions on Independent Slopes Model) approach (Daly et al. 1994, 2002), in particular, has been widely used to map mean annual patterns of precipitation. Using these approaches, values for the different topographic variables are first extracted from raster grids developed in a GIS. Statistical relationships between precipitation totals and the various values taken from the raster grids are then ascertained. Lastly, average annual precipitation totals are estimated for each grid cell using a multivariate regression model and map algebra techniques. Such approaches improve upon traditional geostatistical procedures for precipitation analysis in mountainous regions (i.e. Phillips et al. 1992) by incorporating various topographic variables to create a spatially continuous map of precipitation. Due to the sparse network of precipitation stations in mountainous regions and the inherent challenges of adequately conveying the spatial variability and complexity of precipitation patterns, these GIS approaches have created more accurate and detailed precipitation maps for climate atlases. Once again, however, no work that we are familiar with has developed statistical relationships in conjunction with GIS techniques to assess the relationships between snowfall and different topographic characteristics in mountainous regions. Per- haps it has been done implicitly, by modeling monthly and annual precipitation in areas where the vast majority falls in the form of snow.

A limitation of the reviewed approaches is the use of average annual or average monthly values of precipitation. Precipitation totals over a monthly or annual time scale generally result from a variety of synoptic patterns and associated low-level wind directions. SE low-level flow may predominate in some events, whereas other events may be characterized by NW low-level flow. The physical processes responsible for precipitation development and enhancement will therefore be quite different among synoptic patterns, as will the locations of windward and leeward slopes. Consequently, the relationships between precipitation and topographic characteristics other than elevation are weakened at monthly or annual time scales.

Only a handful of studies that we are familiar with investigate relationships between precipitation and topographic characteristics by low-level wind direction and associated synoptic pattern or flow regime. Houghton (1979) analyzed precipitation-topography relationships in the Great Basin of the western USA by using mean monthly wind direction at the $700 \mathrm{hPa}$ level. His work, however, did not consider wind at the event scale and the associated variability of synoptic patterns within a month. Hill (1983) calculated the average annual orographic enhancement of precipitation by low-level wind direction in England and Wales and plotted maps of the results. Konrad (1995, 1996) analyzed relationships between precipitation event type and topography in part of the Southern Appalachians and found major differences in the strength of the relationships for different low-level wind directions. Lastly, Hayes et al. (2002) used $850 \mathrm{hPa}$ wind and relative humidity from twice-daily radiosonde data to develop a statistical model to estimate precipitation in the central Cascades.

This study builds on the approaches discussed by developing statistical relationships between precipitation and topographic characteristics in the Southern Appalachians, and contributes to this body of literature by (1) focusing specifically on snowfall, (2) linking eventsnowfall totals with a particular low-level wind direction and associated synoptic pattern, and (3) using GIS techniques to develop raster grids of the topographic variables and produce snowfall maps by event type.

\section{STUDY AREA}

The study area was the Southern Appalachian Mountain region (Fig. 1), including areas from northern Georgia to southern West Virginia, along with the Cumberland Plateau in the west and the Blue Ridge 


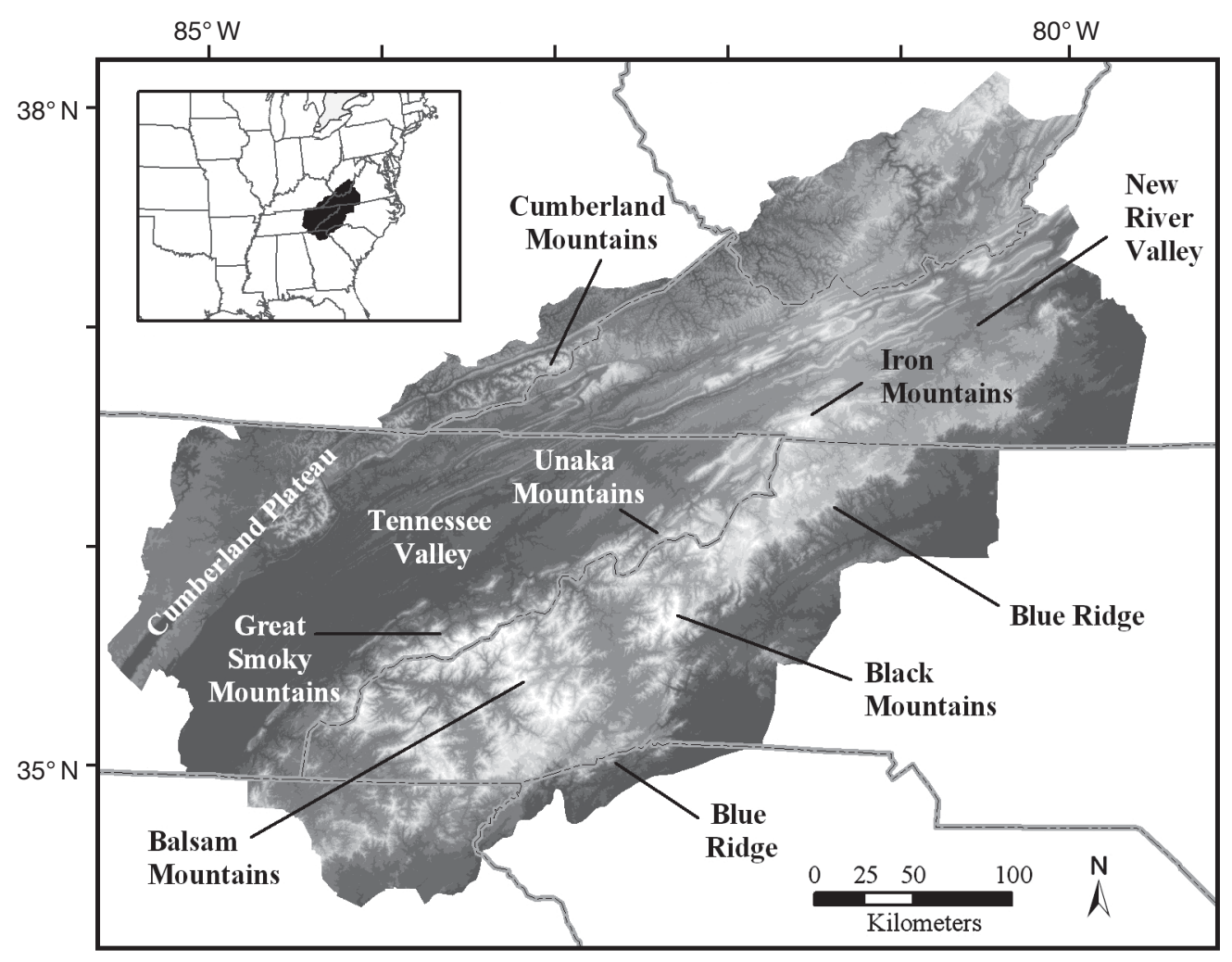

Fig. 1. Map of study area in the Southern Appalachian Mountain region

foothills in the east. The study area trends SW to NE, capturing the general orientation of the topography. The highest elevations and associated greatest relief are found in the mountains of Tennessee and North Carolina, where, for example, the Great Smoky Mountains rise from $<500$ to $>2000 \mathrm{~m}$. Elevations $>1850 \mathrm{~m}$, in fact, are confined to the Great Smoky Mountains and Unaka Mountains of North Carolina/ Tennessee, and to the Balsam and Black Mountains of North Carolina, whereas 1500 m elevations extend into SW Virginia and northern Georgia. Elevated terrain extends northward along the spine of the Appalachians through Virginia and West Virginia, but elevations remain below $1500 \mathrm{~m}$. The Cumberland Plateau in Tennessee and Cumberland Mountains extending NE through eastern Kentucky and extreme SW Virginia are characterized by maximum elevations of 1000 to $1500 \mathrm{~m}$. The Blue Ridge of North Carolina and Virginia rises abruptly from the adjacent foothills to the SE, and elevations generally range between 1000 and $1500 \mathrm{~m}$, although Grandfather Mountain at $1818 \mathrm{~m}$ is an exception. The Tennessee Valley is an expansive low elevation area in eastern Tennessee between the Cumberland Plateau and the North Carolina border. The New River Valley, somewhat higher in elevation than the Tennessee Valley, extends from SW Virginia into southern West Virginia.

\section{NW FLOW SNOWFALL}

NWFS results when low-level NW flow forces cold air to ascend the NW slopes of the Southern Appalachian Mountains. Periods of NW flow typically occur in the wake of a synoptic-scale surface cyclone and cold frontal system, with a cold anticyclone upstream (Fig. 2). In many cases, antecedent upstream

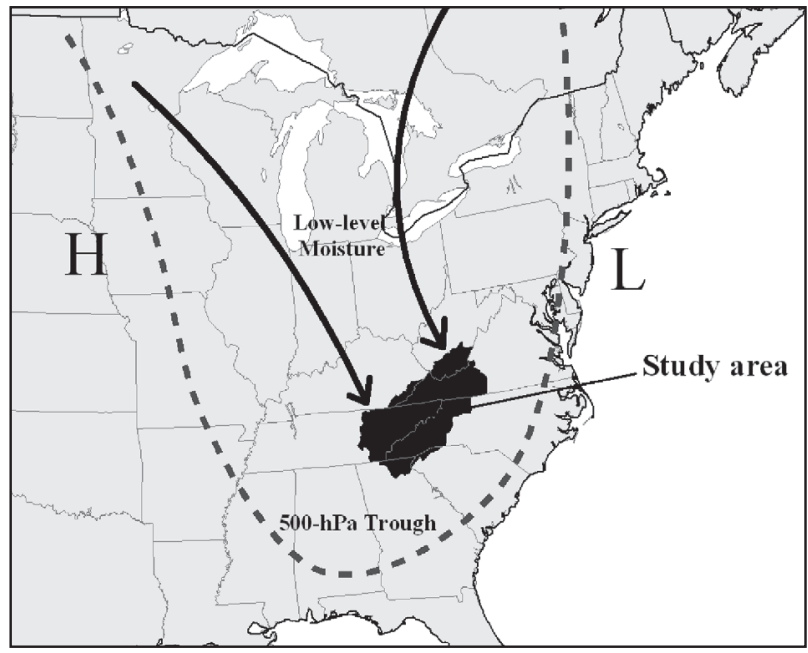

Fig. 2. Typical synoptic pattern for NW flow snowfall (NWFS) 


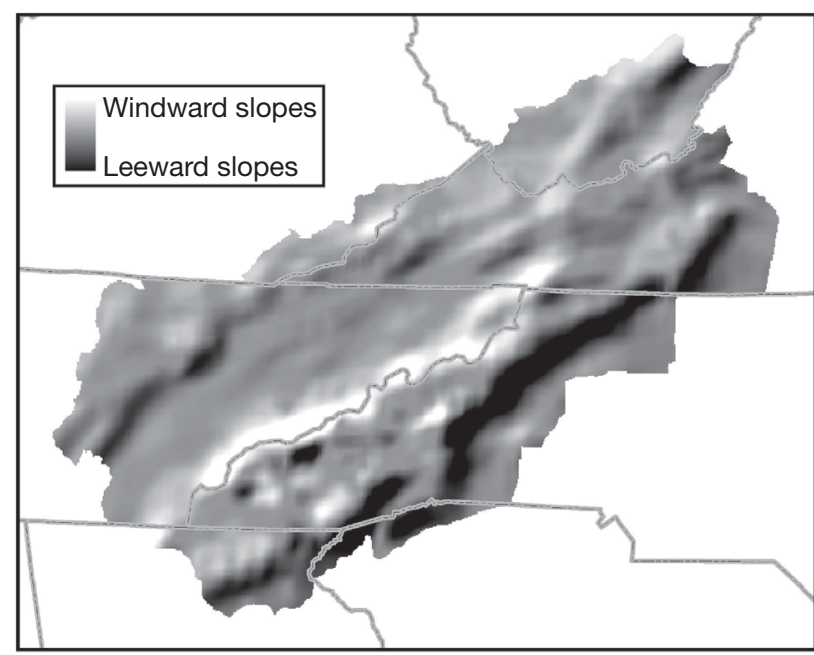

Fig. 3. Locations of windward and leeward slopes $(20 \mathrm{~km}$ resolution) during periods of NW flow

air trajectories cross the Great Lakes, resulting in enhanced snowfall (Perry et al. in press). Due to the general SW to NE orientation of the Southern Appalachians, NW low-level flow is nearly perpendicular to the large-scale topography, producing ideal conditions for orographic lifting. Upslope flow is maximized on NW windward slopes, whereas downslope flow associated with warming and drying occurs on the SE leeward slopes (Fig. 3). NWFS accounts for up to
$50 \%$ of annual snowfall totals on high elevation windward slopes in the region (Perry 2006).

The low temperatures and considerable blowing and drifting of snow, coupled with the significant spatial variability of snowfall, substantially increase the societal impacts of NWFS events. In some cases snowfall is heavy, as evidenced by the widespread totals of 51 to $76 \mathrm{~cm}$ along the windward slopes and higher elevations of eastern Tennessee and western North Carolina during an event on 18-20 December 2003. Other significant late-season NWFS events occurred during 2-6 April 1987 (up to $152 \mathrm{~cm}$ ) and 6-9 May 1992 (up to $102 \mathrm{~cm}$ ) (NWS 1987, Sabones \& Keeter 1989, Fishel \& Businger 1993). More commonly, however, NWFS results in lighter accumulations and occurs in association with mid-level synoptic-scale subsidence and moisture limited to $<700 \mathrm{hPa}$, with topography and convection providing the necessary forcing. In these situations, the lower troposphere may be conditionally or absolutely unstable, thus allowing shallow convection to develop (Perry et al. in press).

\section{DATA AND METHODS}

Daily snowfall records for the period 1988-2000 served as the source of the daily snowfall data. We chose the above $12 \mathrm{yr}$ period since dependable snowfall data only became available in 1988 for 2 stations

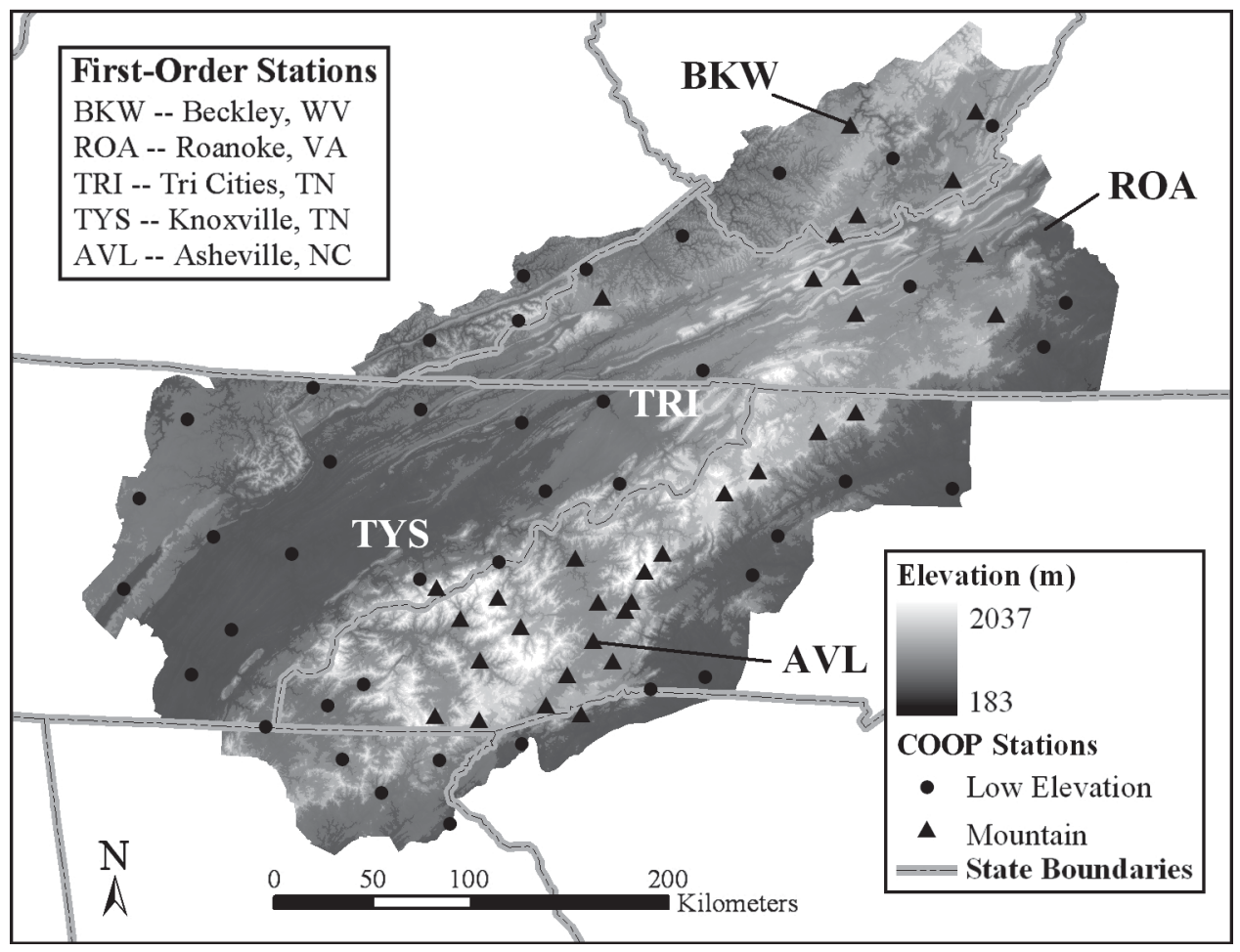

Fig. 4. Topography of study area and COOP stations used in the study 
above 1900 meters: Mt. Leconte, Tennessee, and Mt. Mitchell, North Carolina. We extracted the snowfall data from the National Climatic Data Center's Cooperative Summary of the Day CD-ROM (NCDC 2002) for 76 cooperative observer (COOP) stations in the Southern Appalachian Mountains (Fig. 4). Stations below $600 \mathrm{~m}$ (1969 ft) were classified as 'low elevation' while those above $600 \mathrm{~m}$ were classified as 'mountain.' COOP stations below $600 \mathrm{~m}$ are found primarily in broad river valleys (i.e. Tennessee Valley) or Piedmont locations, whereas COOP stations above $600 \mathrm{~m}$ represent a greater variety of topographic characteristics, including sheltered mountain valleys, mountain slopes, and ridge tops. Since most cooperative observers are volunteers, the quality of the data can sometimes be a concern, particularly with snowfall and snow depth measurement (Robinson 1989). Moreover, even when observers follow standardized procedures for measuring snowfall, variation may still exist within the same town due to inter-observer variability (Doesken \& Leffler 2000). The observation times of the COOP data also introduce some inconsistency for snowfall measurement, as some stations report at 07:00 $\mathrm{h}$, others at 17:00 h, and a handful at 00:00 h. Strong and gusty winds often accompany NWFS events, resulting in measurement challenges and possible inconsistencies among the COOP stations.

We defined a snowfall event as having occurred if at least 1 COOP station in the region reported snow accumulation on a given date. To improve the temporal resolution of each event, we then referenced hourly surface observation summaries from 5 nearby first order stations (Fig. 4). From interpretation of these data, we were able to approximate the onset, maturation, and ending time as well as the duration of reported snowfall across the region. Assessment of the maturation time involved determining the hour in which the spatial extent of snowfall was greatest across the network of firstorder stations. An event remained active if precipitation was reported during a $6 \mathrm{~h}$ period. When precipitation was no longer reported at any of the 5 first order stations for $>6 \mathrm{~h}$, we defined the event as having ended at the hour precipitation was last reported. In situations where snowfall events
Table 1. Topographic and geographic variables analyzed in this study

\begin{tabular}{|c|c|c|}
\hline Variable & Definition & Units \\
\hline ELEV_pt & Station Elevation & $\mathrm{m}$ \\
\hline ELEV01 & 1-km mean elevation & $\mathrm{m}$ \\
\hline ELEV01_z & 1-km mean elevation & $z$-value \\
\hline ELEV10 & 10-km mean elevation & $\mathrm{m}$ \\
\hline ELEV20 & 20-km mean elevation & $\mathrm{m}$ \\
\hline EXPONW_50 & 50-km exposure towards NW & $z$-value \\
\hline EXPONW_100 & 100-km exposure towards NW & $z$-value \\
\hline EXPONW_200 & 200-km exposure towards NW & $z$-value \\
\hline ELEVEXPONW_50 & ELEV01_z + EXPONW_50 & $z$-value \\
\hline ELEVEXPONW_100 & ELEV01_z + EXPONW_100 & $z$-value \\
\hline ELEVEXPONW_200 & ELEV01_z + EXPONW_200 & $z$-value \\
\hline DISNWSLOPE & Distance upwind to a NW slope & $\mathrm{km}$ \\
\hline SLOPE01_10KNW & 1-km mean slope at $10 \mathrm{~km}$ to $\mathrm{NW}$ & $z$-value \\
\hline SLOPE10_10KNW & $10-\mathrm{km}$ mean slope at $10 \mathrm{~km}$ to NW & $z$-value \\
\hline SLOPE20_10KNW & $20-\mathrm{km}$ mean slope at $10 \mathrm{~km}$ to NW & $z$-value \\
\hline LAT & Latitude & Decimal degrees \\
\hline LONG & Longitude & Decimal degrees \\
\hline
\end{tabular}
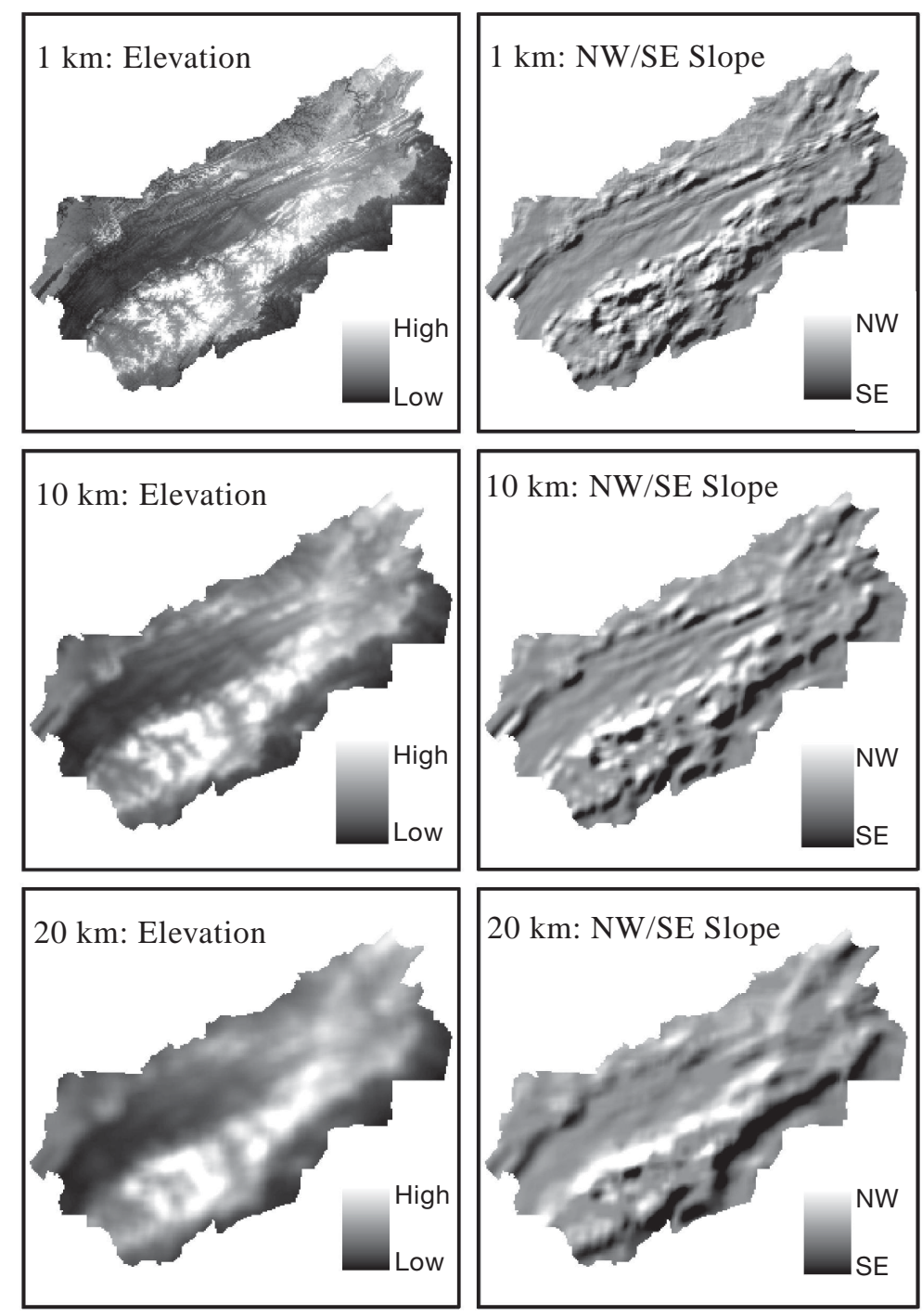

Fig. 5. Mean elevation and slope at $1 \mathrm{~km}, 10 \mathrm{~km}$, and $20 \mathrm{~km}$ resolutions 
occur $<24$ h apart, a small portion of a COOP station's event-snowfall total may be attributed to the prior or subsequent event due to different reporting periods.

We used gridded $\left(2.5^{\circ}\right.$ latitude $\times 2.5^{\circ}$ longitude mesh), twice-daily synoptic fields that were extracted from CDROMs containing the National Center for Environmental Prediction (NCEP) reanalysis dataset (Kalnay et al. 1996) to obtain the $u$ (east-west) and $v$ (north-south) components of $850 \mathrm{hPa}$ wind direction, and surface temperature. These data were then spatially interpolated onto a $1776 \mathrm{~km}$ grid (197 km resolution), with the center grid corresponding to the mean center (weighted by COOP snowfall totals) of each snowfall event. Using the 00:00 and 12:00 h UTC gridded synoptic fields, we undertook a temporal interpolation to estimate field values during the event maturation time. We used an inverse distance technique to carry out all spatial and temporal interpolations. Using these spatially and temporally interpolated data, we identified 188 NWFS events from all snowfall events on the basis of NW (270 to 360 degrees) $850 \mathrm{hPa}$ wind direction at maturation hour. The wind direction at the $850 \mathrm{hPa}$ level, found at approximately

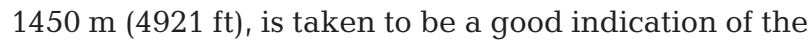
mean wind direction between 1000 and $2000 \mathrm{~m}$ (3280 to $6562 \mathrm{ft}$ ), where it is likely that much of the orographic enhancement in association with NWFS occurs. Although there was significant local scale variation in wind, our interest was to only select snowfall events that displayed a common (NW) synoptic-scale wind direction. We further stratified the sample of NWFS events between cold $\left(<2^{\circ} \mathrm{C}\right)$ and warm $\left(>2^{\circ} \mathrm{C}\right)$ events using the NCEP reanalysis surface temperature field at event maturation hour, which yielded 84 cold and 104 warm events. Preliminary work showed that the influence of elevation on temperature overrides the role of exposure and the other topographic variables. The influence of the other topographic variables, therefore, may be strengthened when temperatures are low enough for snow at nearly all elevations.
The TOPO/GEOG variables (Table 1) used in this study were obtained from GIS raster grids at $1 \mathrm{~km}$ spatial resolution, except for the COOP station point elevation values, which came from the COOP station metadata (NCDC 2002). The original source for the topographic grids were the 1:250 000 scale DEMs from the United States Geological Survey (USGS 2004), which we resampled from approximately $90 \mathrm{~m}$ to $1 \mathrm{~km}$ spatial resolution in a GIS using cubic convolution. In addition to a $1 \mathrm{~km}$ elevation grid, we also developed standardized elevation $z$-values for each $1 \mathrm{~km}$ grid cell and calculated the mean elevation for a 10 and $20 \mathrm{~km}^{2}$ area centered on each grid cell (Fig. 5). Positive relationships have been identified between precipitation and elevation in the Southern Appalachians (Donley \& Mitchell 1939, Smallshaw 1953, Konrad 1996) and in other mountainous regions (Barry 1992, Basist et al. 1994). Pedgley (1970) and Konrad (1996) further suggested that the 'smoothed topography' may actually be a better measure of the influence of elevation on precipitation at specific points. Sharples et al. (2005) confirmed that the optimal horizontal scale for elucidating precipitation-topography interactions in Australia is 5 to $10 \mathrm{~km}$. The airflow is presumably sufficiently modified at this horizontal scale to maximize orographic enhancement. Finer scale topographic features, such as knife ridges and isolated peaks, have less impact on airflows. Latitude and longitude grids were developed using the coordinates for the center of each grid cell from the $1 \mathrm{~km}$ DEM in order to assess synoptic-scale differences in temperature and storm tracks that influence snowfall patterns.

The exposure to the NW (EXPONW) grids (Fig. 6) were derived by subtracting the elevation of each $1 \mathrm{~km}$ grid cell from the elevation of the highest point within a specified radius $(50,100$, or $150 \mathrm{~km})$ to the NW $(270$ to 360 degrees) and then converting these values to standardized $z$-values. An example from 2 stations in the Great Smoky Mountains further illustrates this
Fig. 6. Exposure to the NW (EXPONW) based on $1 \mathrm{~km}$ DEM data
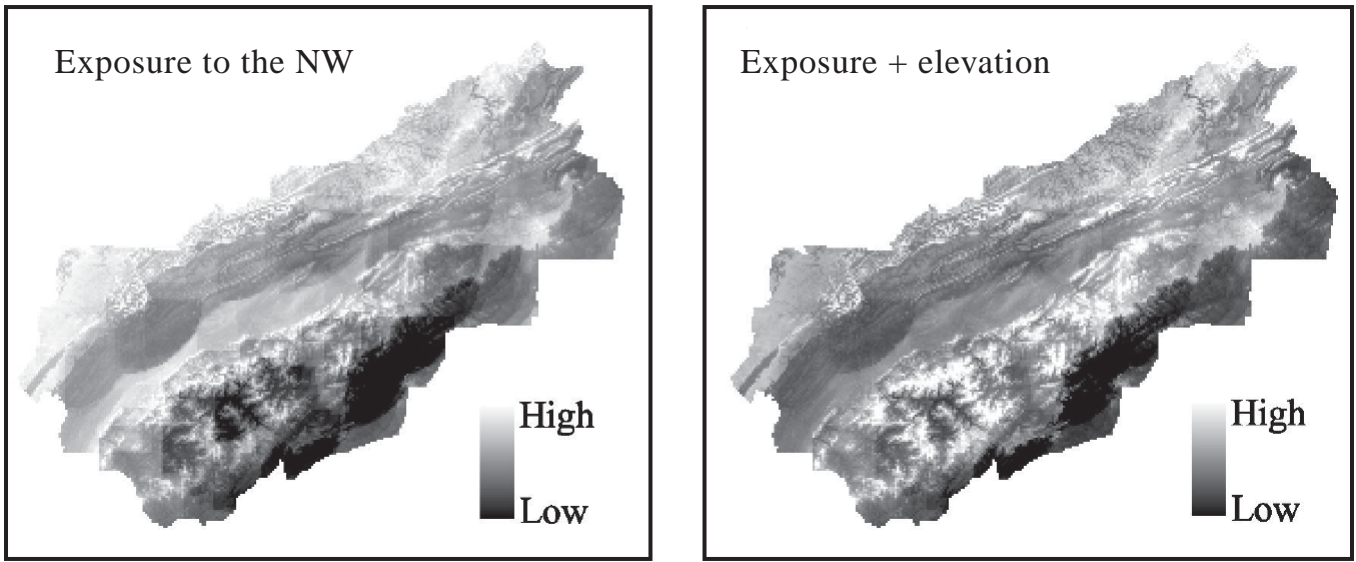
methodology. Oconaluftee, North Carolina, at $622 \mathrm{~m}$

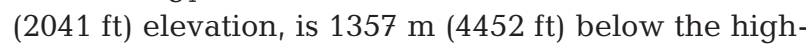
est point to the NW, thus yielding a highly negative $z$-value of $-2.24 z$ (Fig. 7). On the other hand, Mt.

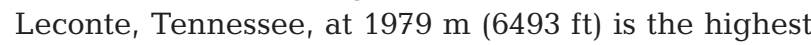
COOP station in the region and therefore exhibits a positive $z$-value of $1.15 \mathrm{z}$. Konrad (1996) employed a similar technique to calculate exposure in his study of precipitation in the southern Blue Ridge, while Basist et al. (1994) also incorporated an exposure variable. These 2 previous studies defined exposure as the distance upwind to a blocking barrier $150 \mathrm{~m}$ (Konrad 1996) or $500 \mathrm{~m}$ (Basist et al. 1994) higher than the station. Our measure defines exposure on the basis of the elevation of the highest upwind blocking barrier within a specified distance, which we think better captures the differing shadowing effects from upstream relief.

We calculated the elevation plus exposure to the NW (ELEVEXPONW) grids (Fig. 6) by adding together the standardized $z$-values of $1 \mathrm{~km}$ elevation (ELEV01) and EXPONW. Utilizing the example in the preceding paragraph, the values are $1.41 \mathrm{z}$ for Oconaluftee and $7.30 \mathrm{z}$ for Mt. Leconte. The interaction of exposure and elevation is perhaps a better indicator of the potential for orographic lifting than just exposure or elevation alone. For example, one location may be highly exposed but at too low an elevation for significant orographic lifting of air parcels. On the other hand, a high elevation station may be heavily shadowed by an even

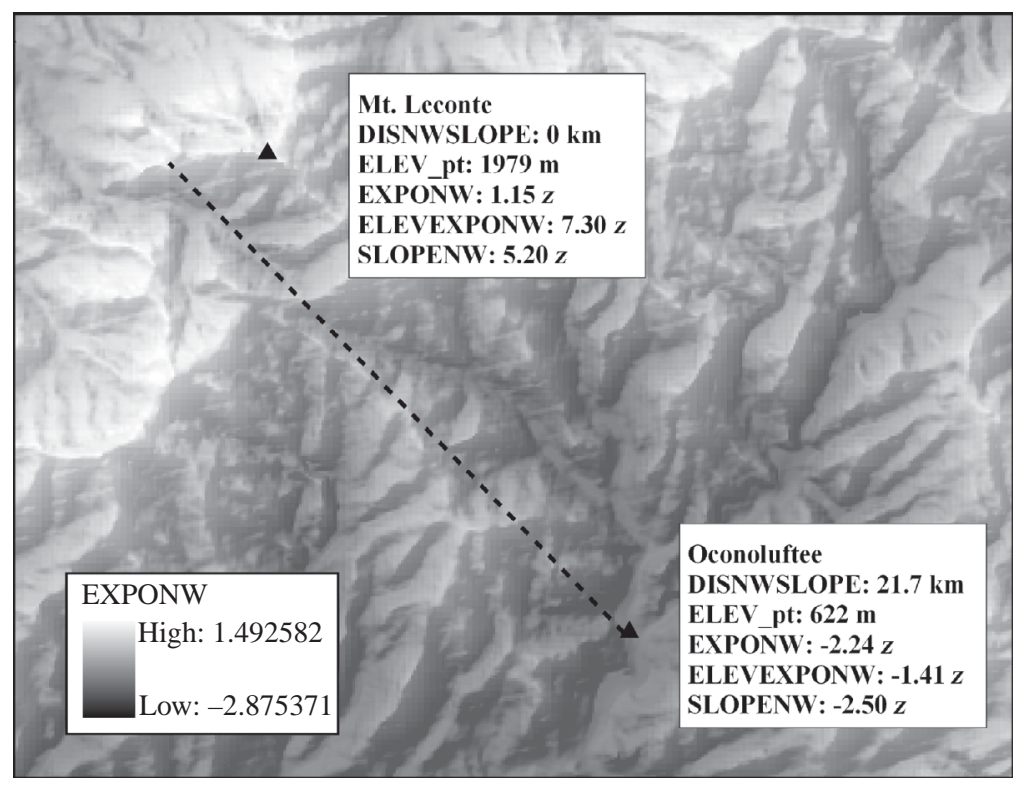

Fig. 7. Exposure to the NW (EXPONW) in the vicinity of the Great Smoky Mountains with topographic variables summarized for Mt. Leconte, Tennessee, and Oconoluftee, North Carolina. Distance and direction to the highest NW slope from Oconoluftee is illustrated by the dashed line. DISNWSLOPE: distance to a NW slope; ELEV_pt: station elevation; ELEVEXPONW: elevation plus exposure to the NW; SLOPENW: slope to the NW higher ridge upwind. A high elevation station that is highly exposed, however, is likely to experience maximum orographic enhancement of precipitation (Houghton 1979, Basist et al. 1994, Konrad 1996).

Distance to a NW slope (DISNWSLOPE) is a variable designed to capture the spillover effects of orographic snowfall. Dore et al. (1992) suggested that snowflakes produced or enhanced through orographic lifting may travel considerable distances downwind of the windward slope, depending on wind speed, before accumulating on the ground. In the example from the Great Smoky Mountains, Mt. Leconte is on a NW slope and therefore has a value of $0 \mathrm{~km}$, whereas Oconoluftee is $21.7 \mathrm{~km}$ downwind. Slope $\left(\mathrm{SLOPE}^{*}\right.$ ) is a final topographic variable included in the analysis and again builds on previous work (Dore et al. 1992, Basist et al. 1994, Konrad 1996). As with elevation, the slope grids (Fig. 5) include measures of the smoothed topography, with a $10 \mathrm{~km}$ mean slope (SLOPE10_10KNW [KNW: $\mathrm{km}$ to the NW]) and a $20 \mathrm{~km}$ mean slope (SLOPE20_10KNW) to the NW. The slope units were also converted to standardized $z$-values, with steep NW slopes having the highest values and steep SE slopes the lowest. In situations of low-level NW flow, terrain-induced rising motions are expected to be strongest where the NW slopes are steepest (i.e. just upwind of Mt. Leconte). Conversely, terrain-induced subsidence is expected to be strongest on the steeper SE slopes (i.e. just upwind of Oconoluftee).

We calculated correlation coefficients for mean annual NWFS by event type and the TOPO/GEOG values. The TOPO/ GEOG values other than ELEV_pt (station elevation) were extracted from the GIS grids and therefore represent the average value across the $1 \mathrm{~km}$ grid cell and may vary substantially from the actual point location of the COOP station. Multivariate regression modeling to estimate mean annual NWFS totals was carried out in SPSS 13.0 (SPSS 2004) using a forward stepwise routine using all variables except ELEVEXPONW_* , which was not included due to obvious concerns about the collinearity of the variable with both ELEV and EXPONW. The model with the highest adjusted $\mathrm{R}^{2}$ was chosen as the final model. To validate the model, we withheld a single observation, calculated the model using the remaining COOP stations, and then repeated this for each observation (a total of 75 iterations). We calculated the model bias and mean absolute error (MAE) using the following formulae 


$$
\begin{aligned}
\text { Bias } & =\frac{1}{\mathrm{n}} \sum_{i=1}^{\mathrm{n}}\left(P_{i}-O_{i}\right) \\
\mathrm{MAE} & =\frac{1}{\mathrm{n}} \sum_{i=1}^{\mathrm{n}}\left|P_{i}-O_{i}\right|
\end{aligned}
$$

In each case, $P_{i}$ is the predicted value and $O_{i}$ is the observed value at each COOP station. An analysis of the residuals for heteroscedasticity and autocorrelation supported original assumptions of the approximately linear relationships in the data. Lastly, a map of estimated mean annual NWFS in the Southern Appalachians was produced by applying the multivariate regression model to the GIS grids of the independent variables using GIS techniques.

\section{RESULTS AND DISCUSSION}

Correlation coefficients between each TOPO/GEOG variable and mean annual NWFS for all stations, mountain stations, and low elevation stations are presented in Table 2. Point elevation displays the highest correlation coefficients for the elevation variables, with the smoothed topography yielding progressively lower coefficients. The low elevation stations are one exception, as $1 \mathrm{~km}$ mean elevation rather than point elevation shows the highest correlation. In the mountain stations, point elevation is likely tied to the strongest correlations because of the strong negative relationship between elevation and temperature. Higher elevations are more likely to be at or below freezing $\left(0^{\circ} \mathrm{C}\right)$, thus encouraging the onset and accumulation of snow. In this case, point elevations are more important for temperature and therefore precipitation type, rather than the liquid equivalent precipitation. These results contrast with those in previous precipitation-topography studies, which found the strongest relationships between precipitation and the smoothed topography (Pedgley 1970, Konrad 1996, Sharples et al. 2005).

The remainder of the topographic variables display the highest correlation coefficients for the mountain stations, since the orographic effects are likely strongest where the relief is the greatest. Little variation in the correlation coefficients is noted for the different search radii $(50,100$, or $150 \mathrm{~km})$ for the exposure grids or the smoothed topography for the slope grids. The geographic variables of latitude and longitude, however, display higher correlation coefficients for the low elevation stations, suggesting the greater relative importance of synoptic-scale processes in influencing snowfall totals. In particular, storm tracks often favor NWFS in the northern and western portions of the study area, while areas to the south and east remain in less favorable synoptic patterns.

Table 2 also presents correlation coefficients between TOPO/GEOG variables and snowfall totals for cold $\left(<2^{\circ} \mathrm{C}\right)$ and warm $\left(>2^{\circ} \mathrm{C}\right)$ events. The correlation coefficients for the elevation variables are considerably higher for the warm events than for the cold events in the case of mountain stations, though minimal difference is noted for the low elevations. In the cold events, temperatures are low enough for snow at almost all elevations, and therefore topographic factors other than elevation are more pronounced. The correlation coefficients for the exposure variables are slightly higher in the cold events, consistent with a diminished influence of elevation as noted above. It is also possible that the stronger relationships between snowfall and exposure are a product of the cloud

Table 2. Correlation coefficients between each variable and both mean annual NWFS and NWFS totals for warm vs. cold events.

\begin{tabular}{|c|c|c|c|c|c|c|c|c|c|}
\hline \multirow[t]{2}{*}{ Variable } & \multicolumn{3}{|c|}{ Annual mean } & \multicolumn{3}{|c|}{ Cold events } & \multicolumn{3}{|c|}{ Warm events } \\
\hline & All Stns & Mtn & Low & All Stns & Mtn & Low & All Stns & Mtn & Low \\
\hline ELEV_pt & 0.75 & 0.71 & 0.45 & 0.68 & 0.61 & 0.42 & 0.79 & 0.78 & 0.49 \\
\hline ELEV01 & 0.69 & 0.60 & 0.70 & 0.64 & 0.50 & 0.68 & 0.70 & 0.67 & 0.68 \\
\hline ELEV10 & 0.58 & 0.47 & 0.43 & 0.54 & 0.39 & 0.41 & 0.58 & 0.54 & 0.43 \\
\hline ELEV20 & 0.47 & 0.31 & 0.35 & 0.45 & 0.24 & 0.34 & 0.48 & 0.38 & 0.36 \\
\hline EXPONW_50 & 0.54 & 0.78 & 0.55 & 0.56 & 0.77 & 0.56 & 0.49 & 0.75 & 0.46 \\
\hline EXPONW_100 & 0.56 & 0.81 & 0.56 & 0.59 & 0.82 & 0.57 & 0.50 & 0.77 & 0.49 \\
\hline EXPONW_200 & 0.56 & 0.82 & 0.56 & 0.60 & 0.82 & 0.58 & 0.50 & 0.77 & 0.48 \\
\hline ELEVEXPONW_50 & 0.82 & 0.84 & 0.64 & 0.79 & 0.78 & 0.65 & 0.82 & 0.87 & 0.58 \\
\hline ELEVEXPONW_100 & 0.83 & 0.86 & 0.65 & 0.80 & 0.79 & 0.65 & 0.83 & 0.88 & 0.60 \\
\hline ELEVEXPONW_200 & 0.83 & 0.84 & 0.65 & 0.79 & 0.77 & 0.65 & 0.83 & 0.88 & 0.60 \\
\hline DISNWSLOPE & -0.32 & -0.55 & -0.33 & -0.37 & -0.60 & -0.37 & -0.24 & -0.48 & -0.21 \\
\hline SLOPE01_10KNW & 0.52 & 0.68 & 0.26 & 0.47 & 0.60 & 0.27 & 0.55 & 0.72 & 0.22 \\
\hline SLOPE10_10KNW & 0.55 & 0.71 & 0.26 & 0.49 & 0.64 & 0.26 & 0.58 & 0.75 & 0.26 \\
\hline SLOPE20_10KNW & 0.44 & 0.71 & 0.19 & 0.39 & 0.63 & 0.19 & 0.47 & 0.76 & 0.19 \\
\hline LAT & 0.39 & 0.40 & 0.72 & 0.48 & 0.49 & 0.71 & 0.26 & 0.27 & 0.68 \\
\hline LONG & 0.26 & 0.15 & 0.29 & 0.30 & 0.23 & 0.27 & 0.20 & 0.05 & 0.35 \\
\hline
\end{tabular}
Mtn: mountain stations; Low: low elevation stations. Bold: $\mathrm{p}<0.05$. See Table 1 for abbreviations 
microphysical environment. Cloud temperatures are more likely to be in the optimal range for dendritic snow crystal growth (-14 to $-17^{\circ} \mathrm{C}$, Fukuta \& Takahashi 1999) in the cold events, suggesting a greater precipitation efficiency on the windward slopes. The seeder-feeder effect produced by orographic lifting is also maximized when dendritic snowflakes are present due to their larger surface area and slower fall speeds (Dore et al. 1992, Whiteman 2000). Scavenging of supercooled liquid water from the low-level feeder clouds is therefore maximized, leaving substantially less low-level moisture for leeward locations downwind. The correlation coefficient for DISNWSLOPE is also slightly higher in the cold events, also suggesting some relationship to the cloud microphysical environment.

The correlation coefficients for the slope variables display a pattern similar to the elevation variables, and are highest for all stations and mountain stations for the warm events. This is likely due to the relationship between high slopes and high elevations, rather than an independent influence of slope on snowfall. Our results with respect to slope are similar to those reported by Konrad (1996) for light NW flow precipitation events in the cool season in the Southern Appalachians. The correlation coefficients associated with the geographic variables of latitude and longitude are somewhat higher for the cold events, particularly in the mountains, suggesting an association between low temperatures and a synoptic pattern that supports more snowfall to the north and west.

The slope of the regression line and the strength of the relationships between the TOPO/GEOG variables and NWFS vary considerably between the low elevation and mountain stations. Differences are particularly evident for point elevation in the warm events and elevation plus exposure for the cold events (Fig. 8). In the lower elevation regions (i.e. Tennessee Valley and foothills), topographic relief and elevation are generally low, resulting in weak orographic effects. In the mountains, however, the greater relief and higher elevations translate into greater spatial variability of snowfall resulting from the topographic influences of elevation, exposure, distance to a NW slope, and slope. Conversely, in the lower elevations the geographic variable of latitude is more highly correlated with NWFS totals than it is in the mountains. The correlation coefficients for longitude are also higher in the lower elevations than the mountains, but the influence of longitude on NWFS remains rather low.
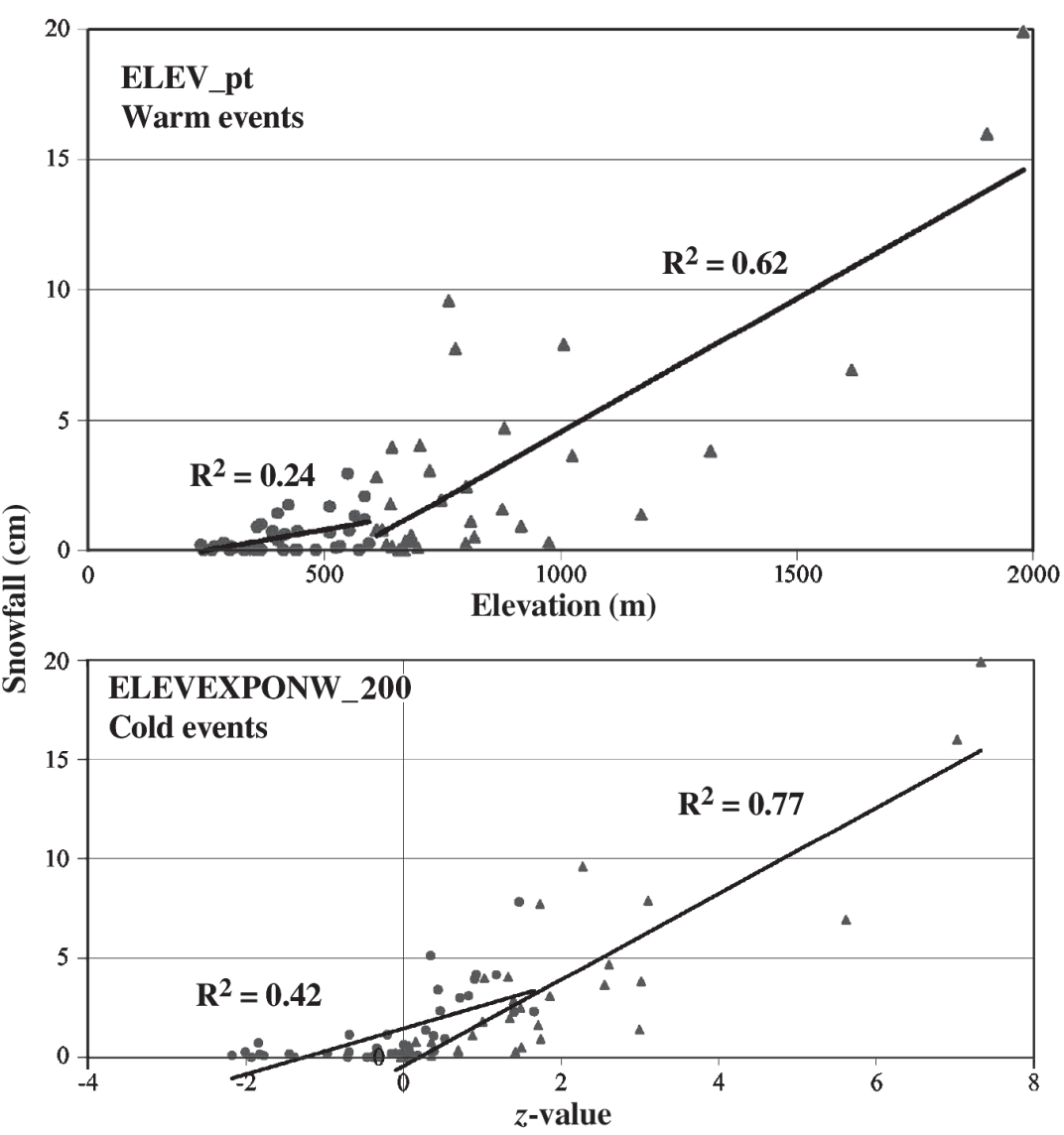

Fig. 8. Plots of mean annual NW flow snowfall (NWFS) against elevation for warm $\left(>2^{\circ} \mathrm{C}\right)$ events (top) and elevation plus exposure for cold $\left(<2^{\circ} \mathrm{C}\right)$ events (bottom). (४) Mountain stations; (•) low elevation stations. ELEV_pt: station elevation; ELEVEXPONW: elevation plus exposure

Table 3 summarizes the final multivariate regression model developed to estimate mean annual NWFS. The best model (identified using a forward stepwise routine for mean annual NWFS and all stations) included the TOPO/GEOG variables of point elevation, exposure, and latitude and explained approximately $73 \%$ of the variance (adjusted $\mathrm{R}^{2}$ ) in mean annual NWFS across the region. Given the inconsistencies and challenges in measuring snowfall (Doesken \& Leffler 2000), this adjusted $R^{2}$ is relatively high. To generate a spatially interpolated map of mean annual NWFS in

Table 3. Final multivariate regression model developed in this study to estimate mean annual NW flow snowfall (NWFS)

\begin{tabular}{|lcc|}
\hline Variable & Definition & Model parameter \\
\hline Intercept & & -81.249 \\
ELEV_pt & Station elevation $(\mathrm{m})$ & 0.014 \\
LAT & Latitude & 2.159 \\
EXPONW_50 & Exposure to NW & 1.395 \\
Adj-R $\mathrm{R}^{2}$ & Adjusted $\mathrm{R}^{2}$ & 0.73 \\
SE & Standard error & 3.64 \\
\hline
\end{tabular}




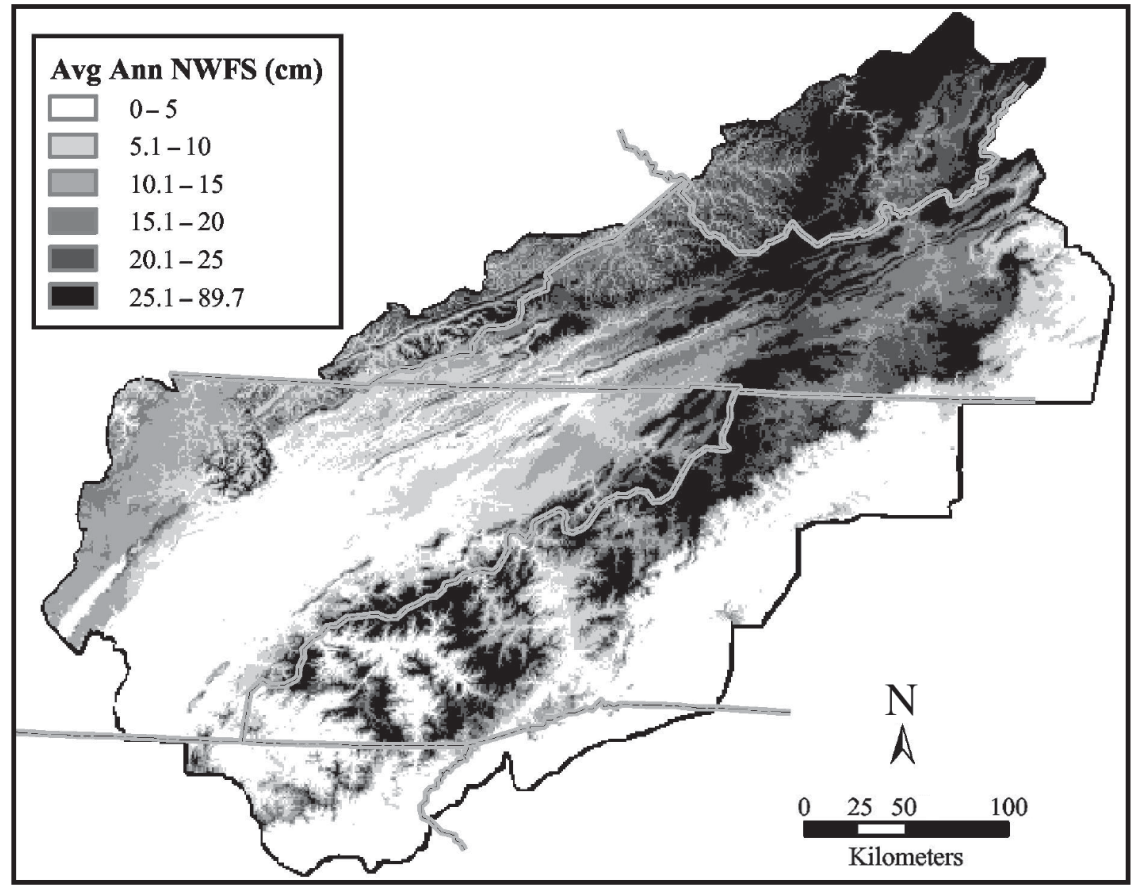

Fig. 9. Mean annual NW flow snowfall (NWFS) as estimated by multivariate regression model

the Southern Appalachians, the multivariate regression model was applied to the GIS grids (Fig. 9). Similar maps could also be developed using the additional multivariate regression models, but elevation remains a dominant influence in all of the models, thereby diminishing the variability in the spatial patterns among different event types. Even though the calcu- lated model bias is negligible $(-0.1 \mathrm{~cm})$, the MAE is considerably higher $(6.9 \mathrm{~cm})$ due to the strong weighting on elevation in the regression model. This results in overly high predictions of snowfall at higher elevations along the Blue Ridge - such as Highlands and Sparta, North Carolina, which are situated to the SE and well downwind of the NW slopes (Fig. 10). By the time the

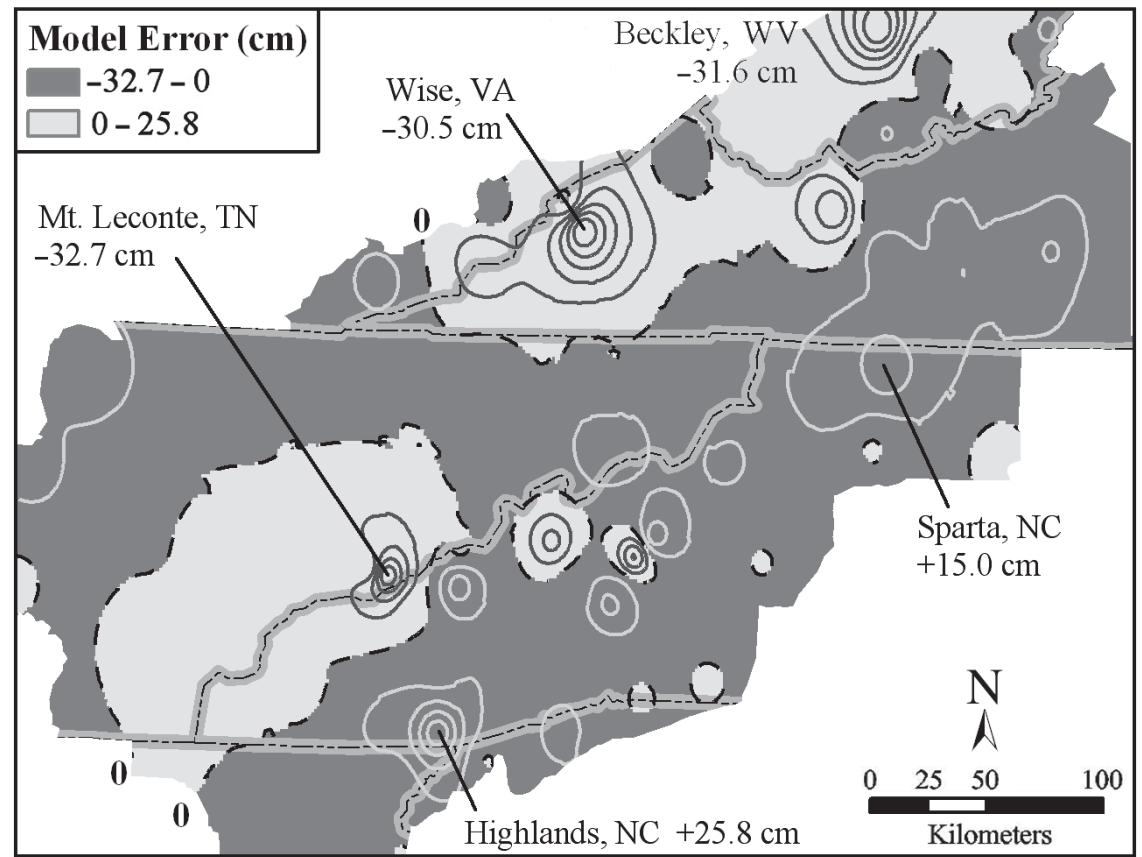

Fig. 10. Errors in the multivariate regression model used to construct the map in Fig. 9. Contour interval: $5 \mathrm{~cm}$ 
low-level NW flow reaches these areas, moisture has been significantly depleted through snowfall and riming upstream. Consequently, little if any accumulation results, even though elevations may be above $1000 \mathrm{~m}$ (3280 ft). A substantial barrier effect is evident, similar to that noted by Schemerhorn (1967) in the Northwest USA. Conversely, NWFS totals are underestimated on the windward slopes, particularly for the most exposed COOP stations of Mt. Leconte, Tennessee; Wise, Virginia; and Beckley, West Virginia (Fig. 10). These errors in the model are most likely related to the relative absence of COOP stations along the higher elevation leeward and windward slopes.

\section{CONCLUSIONS}

We analyzed the relationships between various TOPO/GEOG variables and NWFS in the Southern Appalachian Mountains. Elevation and exposure to the NW most strongly influence the spatial patterns of NWFS in the region. These topographic variables are particularly significant for the higher elevation stations

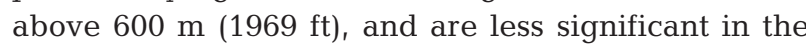
lower elevations where latitude is a more important influence. The relative influence of elevation on NWFS declines in cold $\left(<2^{\circ} \mathrm{C}\right) \mathrm{NWFS}$ events, thereby allowing the influence of exposure to the NW and distance to a NW slope to increase. In warm $\left(>2^{\circ} \mathrm{C}\right)$ NWFS events, elevation is of greater significance due to the adiabatic cooling of air parcels resulting from orographic lifting. In these situations, temperatures at lower elevations may be too warm for snow, but decrease up the mountain slope, allowing precipitation to fall as snow.

This study also presents a methodology linking synoptic climatology and GIS to analyze the relationships between various TOPO/GEOG variables and snowfall totals. By focusing on snowfall patterns associated with a particular wind direction, the topographic influences become more evident, since the locations of windward and leeward slopes are known. This methodology also allows us to derive GIS grids for a variety of TOPO/ GEOG variables and extract values for each of the respective COOP stations in an automated manner, facilitating multivariate statistical analyses. Lastly, the methodology presented in this paper uses output from a multivariate regression model to develop a map of mean annual NWFS using GIS grids of the TOPO/ GEOG variables and map algebra techniques in a GIS.

The COOP stations used in this study do not adequately represent sites situated at the topographic extremes of the study area, and this may be why relatively stronger (weaker) relationships were identified between snowfall and elevation (other topographic variables). Additional high elevation COOP stations would improve the results considerably, since only 4 COOP stations were available above $1200 \mathrm{~m}(3937 \mathrm{ft})$ elevation. A greater density of COOP stations along the Blue Ridge and on higher elevation windward slopes would also be advantageous. The large areal extent and topographic diversity of the Southern Appalachians coupled with subtle differences in the synoptic climatology across the region may also have resulted in weaker relationships. In particular, the large areal extent may have contributed to slightly weaker (stronger) relationships between topographic (geographic) influences and NWFS in this study. Nonetheless, the results are encouraging, given the less than desirable network of COOP stations and the problems associated with measuring snowfall-particularly in the very windy conditions that often occur with NWFS.

In future work, we plan to employ a similar methodology to analyze the relationships between TOPO/ GEOG variables and snowfall for additional low-level wind directions. In particular, we intend to investigate snowfall patterns in association with SE and southerly low-level flow, since many of the major snowstorms that affect the region transport abundant moisture from the Atlantic and Gulf of Mexico to the SE and south. The relationships may not be quite as strong as noted in this paper, however, due to the much stronger synoptic-scale forcing that accompanies these storm systems. Additional opportunities for future work in other mountainous regions also exist, both in terms of snowfall and in the use of this methodology in association with precipitation data for input into a hydrologic model.

Acknowledgements. The authors thank R. Crepeau, A. Rex, M. Mayfield, G. Dobson, and P. Robinson for helpful comments at various stages of the research.

\section{LITERATURE CITED}

Abbs DJ, Pielke RA (1987) Numerical simulations of orographic effects on NE Colorado snowstorms. Meteorol Atmos Phys 37:1-10

Barry RG (1992) Mountain weather and climate, 2nd edn. Routledge, New York

Basist A, Bell GD, Meentemeyer V (1994) Statistical relationships between topography and precipitation patterns. J Clim 7:1305-1315

Choularton TW, Perry SJ (1986) A model of the orographic enhancement of snowfall by the seeder-feeder mechanism. Q J R Meteorol Soc 112:335-345

Daly C, Neilson RP, Phillips DL (1994) A statistical-topographic model for mapping climatological precipitation over mountainous terrain. J Appl Meteorol 33:140-158

Daly C, Gibson WP, Taylor GH, Johnson GL, Pasteris P (2002) A knowledge-based approach to the statistical mapping of climate. Clim Res 22:99-113

Doesken NJ, Leffler RJ (2000) Snow foolin': accurately measuring snow is an inexact but important science. Weatherwise 53(1):31-37 
Donley DE, Mitchell RL (1939) The relation of rainfall to elevation in the southern Appalachian region. Trans Am Geophys Union 20:711-721

Dore AJ, Choularton TW, Fowler D, Crossley A (1992) Orographic enhancement of snowfall. Environ Pollut 75: 175-179

Farley RD, Hjermstad DL, Orville HD (2000) Numerical simulation of a 4-day early spring storm period in the Black Hills. J Appl Meteorol 39:1299-1317

Fishel GB, Businger S (1993) Heavy orographic snowfall in the southern Appalachians: a late season case study. Postprints, Third National Heavy Precipitation Workshop, National Weather Service/NOAA, Pittsburgh, PA, p 275-284

Fukuta N, Takahashi T (1999) The growth of atmospheric ice crystals: a summary of findings in vertical supercooled cloud tunnel studies. J Atmos Sci 56:1963-1979

Goovaerts P (2000) Geostatistical approaches for incorporating elevation into the spatial interpolation of rainfall. J Hydrol 228:113-129

Hayes PS, Rasmussen LA, Conway H (2002) Estimating precipitation in the central Cascades of Washington. J Hydrometeorol 3:335-346

Hevesi JA, Istok JD, Flint AL (1992) Precipitation estimation in mountainous terrain using multivariate geostatistics. Part I. Structural analysis. J Appl Meteorol 31:661-688

Hill FF (1983) The use of average rainfall maps to derive estimates of orographic enhancement of frontal rain over England and Wales for different wind directions. J Climatol 3:113-129

Houghton JG (1979) A model for orographic precipitation in the north-central Great Basin. Mon Weather Rev 107: 1462-1475

Kalnay E, Kanamitsu M, Kistler R, Collins W and 18 others (1996) The NCEP / NCAR 40-year reanalysis project. Bull Am Meteorol Soc 77:437-471

Katzfey JJ (1995) Simulation of extreme New Zealand precipitation events. Part I. Sensitivity to orography and resolution. Mon Weather Rev 123:737-754

Konrad CE (1995) Maximum precipitation rates in the southern Blue Ridge Mountains of the southeastern United States. Clim Res 5:159-166

Konrad CE (1996) Relationships between precipitation event types and topography in the southern Blue Ridge Mountains of the southeastern USA. Int J Climatol 16:49-62

Marquínez J, Lastra J, García P (2003) Estimation models for precipitation in mountainous regions: the use of GIS and multivariate analysis. J Hydrol 270:1-11

Martínez-Cob A (1996) Multivariate geostatistical analysis of evapotranspiration and precipitation in mountainous terrain. J Hydrol 174:19-35

NCDC (2002) Cooperative summary of the day. Eastern U.S National Climatic Data Center, Asheville, NC

Ninyerola M, Pons X, Roure JM (2000) A methodological approach of climatological modeling of air temperature and precipitation through GIS techniques. Int J Climatol 20:1823-1841

Editorial responsibility: Robert E. Davis,

Charlottesville, Virginia, USA
NWS (National Weather Service) (1987) Snowstorm in the Appalachian region on April 2-5, 1987. Storm Data 29: $6-14$

Oki T, Musiake K, Koike T (1991) Spatial rainfall distribution at a storm event in mountainous regions, estimated by orography and wind direction. Water Resour Res 27: 359-369

Pedgley DE (1970) Heavy rainfalls over Snowdonia. Weather $25: 340-349$

Perry LB (2006) Synoptic climatology of northwest flow snowfall in the southern Appalachians. $\mathrm{PhD}$ dissertation, University of North Carolina at Chapel Hill

Perry LB, Konrad CE, Schmidlin TW (in press) Antecedent upstream air trajectories associated with northwest flow snowfall in the southern Appalachians, USA. Weather Forecast

Phillips DL, Dolph J, Marks D (1992) A comparison of geostatistical procedures for spatial analysis of precipitation in mountainous terrain. Agric For Meteorol 58: 119-141

Poulos GS, Wesley DA, Snook JS, Meyers MP (2002) A Rocky Mountain storm. Part I. The blizzard-kinematic evolution and the potential for high-resolution numerical forecasting of snowfall. Weather Forecast 17:955-970

Pruppacher HR, Klett JD (1997) Microphysics of clouds and precipitation, 2nd edn. D. Reidel, Boston, MA

Robinson DA (1989) Evaluation of the collection, archiving, and publication of daily snow data in the United States. Phys Geogr 10:120-130

Sabones ME, Keeter KK (1989) Late season snowfalls in the North Carolina mountains associated with cutoff lows. In: Lee LG (ed) Postprints, 2nd Nat Winter Weather Workshop, NOAA Tech Memo NWS ER-82, National Weather Service/NOAA, Raleigh, NC, p 230-236

Schermerhorn VP (1967) Relations between topography and annual precipitation in western Oregon and Washington. Water Resour Res 3:707-711

Schmidlin TW (1992) Does lake-effect snow extend to the mountains of West Virginia? Proc 49th Annu East Snow Conf US Army, Cold Regions Research and Engineering Laboratory, Oswego, NY, p 145-148

Sharples JJ, Hutchinson MF, Jellett DR (2005) On the horizontal scale of elevation dependence of Australian monthly precipitation. J Appl Meteorol 44:1850-1865

Smallshaw J (1953) Some precipitation-altitude studies of the Tennessee Valley Authority. Trans Am Geophys Union 34: 583-588

SPSS (Statistical Program for the Social Sciences) (2004) SPSS 13.0 for Windows

USGS (United States Geological Survey) (2004) 1:250000 scale DEMs (Digital Elevation Models). USGS, Sioux Falls, SD. Available at http://edc.usgs.gov/geodata/

Weisse AK, Bois P (2001) Topographic effects on statistical characteristics of heavy rainfall and mapping in the French Alps. J Appl Meteorol 40:720-740

Whiteman CD (2000) Mountain meteorology: fundamentals and applications. Oxford University Press, New York

Submitted: January 11, 2006; Accepted: July 11, 2006

Proofs received from author(s): August 7, 2006 